\title{
Socialpolitik mellem selvforvaltning og stat
}

\author{
Per H. Jensen
}

\section{Indledning}

Med baggrund i krisen i den kapitalistiske $\varnothing$ konomi i de vestlige lande, står velfærdsstatens overlevelsesmuligheder centralt i den samfundsvidenskabelige og politiske debat. Velfærdsstatens fundament smuldrer, og fra alle sider af det politiske spektrum argumenteres stadigt mere heftigt for et politisk alternativ til velfærdsstaten gennem en styrkelse af selvorganiseringen og de sociale netværk.

Fra venstre har senest Mogens Holm ${ }^{1}$ klargjort sine synspunkter. Han argumenterer for at den statsligt organiserede socialpolitik, dels har overflødiggjort selvorganisering, og dels har bidraget til en kontrol og knægtelse af de solidaritetsformer som historisk er udviklet i arbejderklassen. Heroverfor gælder det om at genvinde selvorganiseringens terræn, da »arbejderklassens befrielseskamp«, stadig ifølge Mogens Holm, »starter i klassens selvorganisering, bearbejdelse af erfaringer med undertrykkelse og udvikling af et »selvrådigt« demokrati« (m.u.).

En tilsvarende forståelsesfigur genfindes hos Peter Abrahamson², der bredt formulerer, at marxister, i modsætning til statslige løsninger på arbejderklassens eksistensproblemer, må pege på initiativer, der er selvorganiserede og selvforvaltede.

Begge forfattere fremlægger altså et udviklingsperspektiv, hvorefter dannelsen af organisatoriske alternativer til statens interventioner overfor indkomstbortfald og differentieringer $i$ reproduktionsomkostningerne så at sige foregriber socialismen.

Hverken Holm eller Abrahamson kommer dog særligt langt i en konkretisering af deres bestemmelse af de alternative organiseringsprincipper. Længst kommer Mogens Holm. Han henviser til arbejderklassens forsøg på at udvikle selvstændige organisationsformer overfor indtægtstab i begyndelsen af 1900-tallet. Eksempelvis i form af klassens autonome arbejdsløshedskasser

1. Mogens Holm. »Velfærdsstatspolitik og velfærdsstatskritik« $i$ Kurasje nr. 37, December 1985.

2. Peter Abrahamson. »Fra velfærdsstat til velfærdssamfund? $i$ Nordisk Forum, nr. 43, Vol 19, nr. 3, 1984. 
som svar på arbejdsløshedsproblemerne. Holm understreger, at der ikke er nogen grund til at romantisere de nævnte organisationsformer med hensyn til deres evne til at løse de sociale problemer. Hans referering til disse tidlige erfaringer begrundes primært med, at løsningsforsøgene var »funderet i arbejderklassens egne beslutninger og normer for solidaritet «. Det er disse klassespecifikke livsmønstre, hvis særlige normer og kultur ifølge Mogens Holm er blevet knægtet ved velfærdsstatens fremmarch. F.eks. ved statsliggørelsen af arbejderklassens autonome arbejdsløshedskasser.

Med statsliggørelsen af de autonome arbejdsløshedskasser som eksempel, har også andre forfattere argumenteret for, at offentlig indblanding i klassens reproduktionsforhold har ledt udviklingen på afveje. Det gælder f.eks. Ivar Hornemann Møller ${ }^{3}$ og Hans Erik Avlund Frandsen m.ff. ${ }^{4}$ Disse forfattere argumenterer for, at statsliggørelsen af de autonome arbejdsløshedskasser resulterede i en svækkelse af arbejderklassen i lønkampen. Med Hornemann Møller kan problemstillingen altså formuleres derhen, at arbejderklassen »i hvert fald på langt sigt ville have stået stærkere uden statsliggørelse af dens arbejdsløshedskasser«.

Denne påstand forsøger Frandsen og Møller primært at begrunde ud fra det sagsforhold, at midlerne i de statsliggjorte arbejdsløshedskasser hverken som lån eller gaver måtte tilflyde andre foreninger eller anvendes $\mathrm{i} » u v e d-$ kommende $\varnothing$ jemed «. Denne adskillelse af arbejdsløshedskassernes midler fra fagforeningernes $\varnothing$ konomi opfatter de som en katastrofe. Det udlægges som et beskidt trick der skal forhindre de autonome kassers anvendelse som redskab i klassekampen. Eller som det formuleres hos Frandsen m.fl.: Tidligere »kunne de uafhængige arbejdsløshedskasser til enhver tid - hvis arbejderne foretrak det - gøres til strejkekasser«. Med statsliggørelsen båndlægges imidlertid midlerne i arbejdsløshedskasserne. Stadig med Frandsen m.fl.: »På denne måde kunne man ... binde arbejderne til at bruge deres penge til denne form for forsikring, således at de fik dårligere råd til at betale osse til strejkekasserne«.

Sammenfattes de ovenfor nævnte forfattere, når man frem til en tese om en forfaldshistorie med to komponenter: For det første leder statsliggørelse frem til en knægtelse af arbejderklassens autonome organiseringsprincipper, og for det andet forringer statsliggørelse arbejderklassens stilling i den økonomiske klassekamp.

Ud fra et eksemplificerende materiale er hensigten med denne artikel at vende forfaldstesen på hovedet gennem en diskussion af selvorganiseringens historisk faktuelle betingelser overfor arbejdsløshedsproblemerne. Min

3. Iver Hornemann Møller: »Klassekamp og sociallovgivning 1850-1970« Socialistiske Økonomers Forlag, 1981.

4. Hans Erik Avlund Frandsen m.fl.: »Planøkonomi og Folkefront« København, 1979. 
ambition er i denne forbindelse at give stats- og reformismekritikken jordforbindelse $\mathrm{i}$ en polemik med de nævnte forfattere.

I det historiske materiale opererer jeg med 3 tværsnit. Med statsliggørelsen af de autonome arbejdsløshedskasser i 1907 som omdrejningspunkt diskuterer jeg to historiske yderpunkter: på den ene side arbejderklassens selvorganiserede fors $\varnothing \mathrm{g}$ på at løse arbejdsløshedsproblemerne $f \emptyset r$ 1907, og på den anden side arbejdsløshedsforsikringens evne til at modstå de krisebaserede nedskæringer i 1980'erne. Jeg diskuterer altså statsfunktionernes dannelse og delvise afvikling under den aktuelle krisesituation.

Min tese er, at der er en indre forbindelse mellem de 3 analyserede tidsrum: På denene sidehar arbejdsløshedsforsikringens statslige $»$ institutionaliseringsform $\ll^{5}$ i 1907 sine rødder i de autonome arbejdsløshedskasser. På den anden side har institutionaliseringsformen lagt rammer og betingelser for den senere udvikling og omfunktionering af det arbejdsmarkedspolitiske apparat. I en vis forstand kan man tale om, at den senere udvikling, og dermed evne til at værne om arbejdsløshedsforsikringen, forformes med dannelsesprocessen som historisk udgangspunkt.

I selve forløbsanalysen skal primært inddrages 3 komponenter: Det drejer sig om: 1) Arbejdsløshedskassernes evne til problemløsning; 2) Arbejdsløshedskassernes »indre« organisationsverden, dvs. betingelserne for at oppebære arbejdsløshedsunderstøttelse, kontrollen med de arbejdsløse o.lign.; 3) Arbejdsløshedskassernes generelle organisatoriske form og indkapsling, eller: arbejdsløshedskassernes institionaliseringsform.

\section{Dannelsen af autonome arbejdsløshedskasser}

Mogens Holm fremlægger en opfattelse, hvorefter »arbejderklassen selv« udvikler autonome organiseringsformer, der dog gennem historiens kværnemaskine distanceres stadig mere fra basis. Se f.eks. hans formulering om, at selvorganiseringen udviklede sig til en »mere institutionaliseret organisering igennem fagforeninger og igennem socialdemokratiet«. På de autonome arbejdsløshedskassers område har han uret. Arbejdsløshedskasserne $u d g i k$ fra den tidlige fagbevægelse og tjente såvel et indtægtssikrende som et fagligt formål. I overensstemmelse med sit faglige formål fulgte opbygningen af de autonome arbejdsløshedskasser strukturen i den danske fagbevægelse Arbejdsløshedskassernes organiseringsprincipper har med andre ord rod i den danske fagbevægelses organisatoriske og politiske særtræk.

5. For en nærmere diskussion af begrebet »institutionaliseringsform«, se Bernhard Blanke: »Socialdemokrati og samfundskrise « $i$ Kurasje nr. 29, Oktober 1981. Iøvrigt kan denne artikel ses som et fors $\emptyset \mathrm{g}$ på at konkretisere Blankes overvejelser i den nævnte artikel. 
Den danske fagbevægelse var fra starten domineret af faglærte arbejdere. Den var opdelt efter faglige principper med klare organisatioriske og funktionsmæssige traditioner tilbage til svendelavene. Kvalifikationsmæssige forskelle var grundlaget for organisering og monopoldannelsen på udbuddet af arbejdskraft spillede en central rolle i den faglige kamp. Udover at styrke sig overfor kapitalen, handlede faglig organisering tillige om at afgraense sig fra den $\emptyset$ vrige del af arbejderklassen.

Fra 1880'erne påbegyndtes dannelsen af arbejdsløshedskasser i tilknytning til fagbevægelsen. I første omgang med de lokale fagforeninger som initiativtagere, og fra 1890'erne blev der med forbundene som udgangspunkt dannet forbundskasser ${ }^{6}$. I 1906, dvs. året før statsliggørelsen af arbejdsløshedskasserne, havde 28 forbund og 3 lokale fagforeninger med tilsammen 33.236 medlemmer oprettet arbejdsløshedskasser. Da medlemsskab af arbejdsløshedskasserne indenfor en række fag var frivillig for fagforeningernes medlemmer, betød dette, at ca. $32 \%$ af den fagorganiserede del af klassen havde adgang til at forsikre sig mod arbejdsløshed ${ }^{7}$.

Arbejdsløshedskasserne genspejlede den faglige forgrening i fagbevægelsen. Hvert fag havde sin egen arbejdsløshedskasse, ligesom der medlemsmæssigt og organisatorisk eksisterede en tæt forbindelse mellem de enkelte arbejdsløshedskasser og de respektive fagforeninger.

Dette organiseringskoncept har sin baggrund i, at arbejdsløshedskasserne skulle fungere komplementært til fagforeningerne som markedsorganisationer ved funktionelt at styrke lønkampens betingelser. For det første skulle ar-

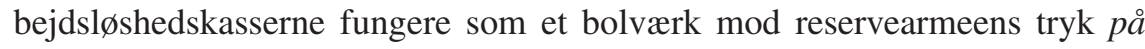
de enkelte delmarkeder. For det andet håbede man, at arbejdsløshedskasserne kunne styrke den faglige organisering. Da deltagelse i forsikringen forudsatte medlemskab i fagbevægelsen, mente man, at kasserne dels kunne fastholde medlemmerne i de endnu noget flygtige fagforeninger, og dels anvendes som rekrutteringsinstrument.

Trods den tætte forbindelse mellem fagforeninger og kasser, udgjorde kasserne selvstændige organisationer med egne love. Dette, i modsætning til Frandsen/Møllers pointe, for at undgå, at der skete en sammenblanding af fagforeningskontingentet/midlerne til strejkekasser og arbejdsløshedskasserne. I De Samvirkende Fagforbunds (DsF; senere LO) blad »Samarbejdet « opfordrede man til stadighed til at holde strejke og arbejdsløshedskasser adskilt ${ }^{8}$, hvad der da også var en almen praksis. F.eks. angives det i statutterne for arbejdsløshedskassen i Dansk Smede- og Maskinarbejderforbund (1893):

6. Den følgende fremstilling bygger bl.a. på Andersen m.fl.: »Klassekamp og reformisme«, Afhandling nr. 8, del 3, 1981, Sociologisk Institut.

7. Andersen m.fl., op.cit.

8. Se f.eks. »Samarbejdet«, nr. 18/1899. 
»Rejse- og understøttelseskassens midler må ikke bruges på anden måde end udtrykkeligt tilladt på sidste kongres ... Strejkende må ikke oppebære hjælp af arbejdsløshedskassen, da de ved strejke foranledigede udgifter bør udredes på anden af kongressen anvist måde « ${ }^{9}$

Mig bekendt er det eneste eksempel på at arbejdsløshedskasserne blev brugt som strejkehjælp kampen om organisationsretten indenfor metalområdet i $1885^{10}$. Dvs. i kassernes allertidligste startfase.

Dette må sættes i sammenhæng med, at arbejdsløshedskasserne udover deres faglige formål tillige tjente et selvstcendigt formål som indtægtssikrende foranstaltning. De fungerede som et alternativ til den kommunale fattighjælp med dens retsvirkninger. Ud fra dette selvstændige formål var arbejdsløshedskasserne, ved siden af sygekasser, begravelseskasser osv. blot én af mange organisationsformer der sigtede på at forbedre arbejderklassens samlede reproduktionssituation indenfor det borgerlige samfund. Det er derfor også forkert når Møller hævder, at arbejdsløshedskasserne i forbindelse med statsliggørelsen udviklede sig fra »at være en selvfølgelig del af en kamporganisation ... (til, m.t) ... nu i nogen udstrækning sociale forsikringskasser « (m.u.). Med sit indtægtssikrende perspektiv spillede det sociale aspekt en meget vigtig rolle for kassedannelsen.

Centrum for kassedannelsen var de faglærtes forbund/fagforeninger. I Dansk Arbejdsmands Forbund og indenfor byggefagene lykkedes det ikke at oprette arbejdsløshedskasser, hvad der skyldes, at disse områder såvel var præget af høj arbejdsløshed som lavt indtægtsniveau. Forudsætningen for kassedannelsen var at indtægten indenfor faget rakte ud over eksistensminimum, og at arbejdsløshedens omfang ikke gik ud over fagets evne til at finansiere understøttelsen. Arbejderklassens egne »normer for solidaritet « var på arbejdsløshedsområdet altså fagligt afgrænset.

For at få ret til arbejdsløshedsunderstøttelse skulle man, afhængig af kasse, ugentligt have bidraget til kassen i 1-2 år; den arbejdsløse skulle dokumentere at arbejdsløsheden var uforskyldt, skulle møde til kontrol og tage anvist arbejde. I »Samarbejdet « anbefalede man, at kontrollen skulle være betryggende med henblik på at undgå misbrug. Thi

»når man står i en fagforeninge hvor kammeraterne er med til at betale understøttelsen vil man passe nøje på, at ingen får adgang til at nyde understøttelse, uden at det også er berettiget $\ll^{11}$.

9. Love for DSMF (1893), § 16 og 19.

10. O. Bertolt m.fl.: »En bygning vi rejser« København, 1955.

11. »Samarbejdet $\ll$, nr. $24 / 1902$. 
At kontrollen da også har været fuldt betryggende vil fremgå af, at kontrollen i f.eks. Dansk Smede- og Maskinarbejderforbund blev forestået af en tillidsmand, der selv var pligtig at erstatte arbejdsløshedskassen det fulde beløb, hvis han havde foranlediget en uberettiget udbetaling ${ }^{12}$.

Arbejdsløshedskasserne og kontrollen med de arbejdsløse var en af drivkræfterne bag dannelsen af faglige arbejdsanvisningskontorer. Ud fra kontrolaspektet anså man oprettelsen af et anvisningskontor som en nødvendig følge af oprettelsen af forsikringskasser, idet man mente, at arbejdsanvisningen havde en beskæftigelseseffekt, der ville skåne kasserne for adskillige udbetalinger i tidens $l \varnothing b^{13}$. I kontrollen med de arbejdsløse indgik endvidere en mobilitetsdimension, hvor man dog skelnede mellem gifte og ugifte medlemmer. Kun gifte medlemmer kunne direkte nægte at tage anvist arbejde udenfor den by, hvor de var bosat.

Ved siden af sin funktionelle sammenhæng med arbejdsløshedsforsikringen blev også arbejdsanvisningen betragtet som et støttepunkt i den faglige kamp. Ved at dagforeningerne tilkæmpede sig eneret på anvisningen af arbejde indenfor de respektive fag, kunne arbejdsanvisningen fungere som et rekrutterende organ til de faglige organisationer, og dermed virke underst $\varnothing$ ttende på fagbevægelsens fors $\varnothing \mathrm{g}$ på at tilkæmpe sig en monopolsituation i udbuddet af arbejdskraft. Det var dog først og fremmest indenfor de mest velkonsoliderede forbund, at det lykkedes at oprette en arbejdsanvisning.

Iøvrigt kan også arbejdsanvisningen anvendes til at anskueliggøre arbejderklassens »normer for solidaritet « $\mathrm{i}$ begyndelsen af 1900-tallet. I en kommentar til Københavns Kommunale Anvisningskontor (oprettet i 1899) formulerer Dansk Smede- og Maskinarbejderforbund sit praktiske syn på anvisningsformen: »først fyret, først i arbejde.« Det hedder således, at man må erkende, at der faktisk findes »folk, der ikke kan drive en pind i et uartigt ord uden at $\emptyset$ delægge begge dele«. Problemet med anvisning i rækkefølge er som følge heraf, at

»arbejdsgiverne holder op med at benytte kontoret, fordi de tror at de nødvendigvis skal belemres med den arbejdskraft, der ikke kan bruges ${ }^{14}$

I skriftet »Det kommunale arbejdsanvisningskontor « angiver Ludvig Petersen ${ }^{15}$ da også, at der stort set ikke var nogen fagforeninger der anviste i rækkefølge.

12. Love for DSMF (1893), $\S 19$.

13. »Samarbejdet «, nr. 18-19/1899.

14. »Fagbladet for Smede og Maskinarbejdere«, nr. 8/1905.

15. Ludvig Petersen: »Det kommunale arbejdsanvisningskontor« København, 1901. 


\section{Statsliggørelsen af arbejdsløshedskasserne}

Mellem de autonome arbejdsløshedskasser og fagforeningerne eksisterede et gensidigt virkende forhold mellem eksistenssikring og lønkamp. Fra 1890 'erne, dvs. parallelt med dannelsen af forbundskasser, ønskede man fra arbejderbevægelsens side at styrke og cementere denne relation gennem statslige reformpolitiske tiltag, idet man stillede krav om en statslig subsidiering af de autonome arbejdsløshedskasser. I 1907 imødekommes arbejderbevægelsens målforestillinger gennem en lovgivning på området, hvorefter allerede eksisterende eller nytilkomne kasser kunne søge om statsanerkendelse og derigennem få tilskud fra det offentlige. Efter denne tilskudsordning videreførte 1907-reformen de organisatoriske traditioner med fagligt adskilte arbejdsløshedskasser, ligesom statsanerkendelsen ikke skar den tætte kontakt mellem fagbevægelse og arbejdsløshedskasserne (de arbejdsløse) over.

For arbejderbevægelsen var målsætningen med de offentlige interventioner på forsikringsområdet dobbeltsidet.

For det første $\varnothing$ nskede man at skabe grundlag for dannelsen af kasser indenfor lavtlønsområderne, hvor en opbygning af arbejdsløshedskasser havde vist sig enorm vanskelig. Som et direkte resultat af loven blev der oprettet arbejdsløshedskasser indenfor byggefagene (murere, tømrere) og i Dansk Arbejdsmands Forbund. I forlængelse af lovens vedtagelse skete der en vækst i antallet af forsikrede fra ca. 30.000 (1906) til ca. 70.000 i 1907/08. Dermed var ca. $62 \%$ af de fagforeningsmæssigt organiserede lønarbejdere medlem af en arbejdsløshedskasse. Reformen frigjorde med andre ord store dele af de arbejdsløse indenfor lavtlønsområderne fra fattigvæsenet.

For det andet $\emptyset$ nskede man at styrke økonomien i de eksisterende kasser. Det svage punkt i de autonome arbejdsløshedskasser var, at de ofte var $\varnothing$ konomisk svagt funderet. Selvom der statut-mæssigt var nedlagt regler for understøttelsens størrelse og varighed m.v., blev underst $\varnothing t t e l s e n$ de facto afvejet efter kassernes $\emptyset$ konomi. Via de statslige subsidier kom arbejdsløshedskasserne til at fungere langt mere regelmæssigt. For Dansk Smede- og Maskinarbejderforbund betød 1907-loven, at støtteperioden kunne sættes op fra 70 til 80 dage pr. år, og at kontingentet til kassen kunne nedsættes fra kr. 0,35 til kr. 0,27 pr. uge. Denne difference tilfaldt dog ikke det enkelte individuelle medlem, men blev overført til strejkekassen. For en række fag betød statsliggørelsen af arbejdsløshedskasserne altså en økonomisk styrkelse af strejkekasserne!!

\subsection{De statslige kontrolforanstaltninger}

De statsliggjorte arbejdsløshedskasser blev baseret på selvforvaltningsprincipper. Den daglige administration blev forestået af arbejdsløshedskassens bestyrelse, som var valgt af medlemmerne i arbejdsløshedskassen. Dog blev der ført kontrol med kassernes generelle administrationspraksis. 
Den statslige kontrol blev lagt i hænderne på »Arbejdsløshedsnævnet«, der udover en af staten udpeget arbejdsløshedsinspektør bestod af 6 af arbejdsløshedskasserne for 6 år valgte repræsentanter. I praksis 6 forbundsformænd. Der var altså en massiv lønarbejdermajoritet i det statslige kontrolinstrument.

Selve kontrollen med de arbejdsløse fulgte tillige autonome principper, idet tilsynet og kontrollen med de arbejdsløse ifølge loven skulle foretages af arbejdsløshedskassens bestyrelse. Dog anbefalede man fra DsF/Arbejdsløshedsnævnets side, at konstrollen med de arbejdsløse blev overdraget fagforeningernes arbejdsanvisningskontorer. På denne baggrund opfordrede man til dannelsen af arbejdsanvisningskontorer indenfor de fag hvor sådanne endnu ikke forefandtes. Bl.a. Dansk Arbejdsmands Forbund oprettede som følge heraf en arbejdsanvisning i $1908^{16}$.

De kontrolforanstaltninger som var indbygget i 1907-loven gav langt fra anledning til en skærpelse af administrationspraksis. Ifølge Dansk Smede- og Maskinarbejderforbund ville arbejdsløshedskassen efter statsliggørelsen da også $» \ldots$ virke ganske på samme måde som hidtil $\ll^{17}$. Med en konsolidering af strejkekasserne som biprodukt kan man endda forfægte, at 1907-loven gav anledning til en styrkelse af den funktionelle sammenhæng mellem fagforeningerne, arbejdsløshedskasserne og arbejdsanvisninghen, og dermed $l \phi n$ kampens betingelser. Dels fordi arbejdsløshedskasserne som bolværk mod reservearmeens tryk omfangsmæssigt og $\varnothing$ konomisk blev bedre funderet, og dels fordi 1907-loven virkede som en katalysator for udbredelsen af fagforeningsmæssige arbejdsanvisningskontorer.

Arbejdsgiverne reagerede da også negativt på 1907-loven. Særligt var man utilfreds med at kontrollen med de arbejdsløse blev foretaget af fagforeningernes arbejdsanvisningskontorer. Man hævdede, at »arbejdsløshedskasserne er ... et appendiks til fagforeningerne «, og at fagforeningslederne end ikke »kunne se det umoralske $\mathrm{i}$ at drive arbejdsanvisning som led i lønstriden og på kassernes bekostning ${ }^{18}$. Som følge heraf stillede man krav om mere statskontrol med de arbejdsløse gennem oprettelsen af en statsligt organiseret arbejdsanvisning.

Ved lov af 1913 blev arbejdsgivernes kritik delvist imødekommet via dannelsen af et net af kommunale arbejdsanvisningskontorer.

1913-loven var en rammelov der gav kommunerne mulighed for at oprette arbejdsanvisningskontorer. Det københavnske anvisningskontor, der allerede blev oprettet i 1899, skulle fungere som centralkontor for hele landet. Samtidig blev der tilkoblet en overledelse bestående af en arbejdsanvisningsdirektør

16. »Arbejdsmændenes Fagblad, nr. 3/1908.

17. »Fagblad for Smede og Maskinarbejdere«, nr. 3/1908.

18. »Arbejdsgiveren«, nr. 26/1911. 
udpeget af indenrigsministeriet og 10 medlemmer som var sammensat af et lige stort antal arbejdsgivere og arbejdere ${ }^{19}$.

Loven påbød et samarbejde mellem de kommunale anvisningskontorer og afdelingerne af de statsanerkendte arbejdsløshedskasser. Ugentligt skulle arbejdsløshedskasserne aflevere en fortegnelse over de af arbejdsløshedskassernes ledige medlemmer som oppebar underst $\varnothing$ ttelse til de kommunale anvisningskontorer. Den kommunale arbejdsanvisning fik dog ikke eneret på arbejdsanvisningen, men skulle fungere side om side med fagforeningernes anvisningskontorer. Dermed var skabt det dobbeltstrengede anvisningssystem som eksisterede frem til 1969.

1913-reformen om arbejdsanvisning indebar en fornyelse på to felter:

For det første blev det muligt at oprette kommunale anvisningskontorer i provinsen. Allerede i 1899 var der med fagbevægelsens tilslutning oprettet et kommunalt anvisningskontor i København, som tilsigtede anvisningsfunktioner overfor de grupper på arbejdsmarkedet som ikke selv evnede at oprette et fagforeningsmæssigt arbejdsanvisningskontor; først og fremmest de ufaglærte. Det københavnske anvisningskontor bidrog til at gennemsigtigg øre det københavnske arbejdsmarked. Med 1913-loven var denne gennemsigtiggørelse bragt op på nationalt niveau. Dvs. at 1913-loven var et institutionelt støttepunkt for dannelsen af et nationalt arbejdsmarked. Som tilfældet havde været ved oprettelsen af det københavnske arbejdsanvisningskontor, blåstemplede DsF 1913-loven. Dels fordi kun ca. 60.000 arbejdere i 1911 var omfattet af en faglig arbejdsanvisning ud af en samlet organiseret arbejdsstyrke på 128.000, og dels fordi loven bidrog til en regulering af det uorganiserede arbejdsmarked. F.eks. blev det forbudt at drive privat anvisning i form af fæstekontorer o.lign.

For det andet greb loven ind overfor den snævre kobling mellem arbejdsløshedskasser, arbejdsanvisning og fagforeninger. Fra de faglærte forbunds side frygtede man dog ikke, at den offentlig arbejdsanvisning med tiden skulle afløse eller overflødiggøre fagets arbejdsanvisning. Men var overbevist om, at en faglært arbejdsanvisning forudsatte et personalekendskab, som den offentlige arbejdsanvisning ikke kunne komme i besiddelse af. Man mente således, at den kommunale anvisning primært ville få betydning for de ufaglærte ${ }^{20}$. Gennem godkendelsen af 1913-loven accepterer man med andre ord, at den faglige sektionalisme som blev reproduceret på arbejdsløshedskassernes område med 1907-reformen, tillige overvintrer indenfor det offentlige arbejdsanvisningssystem. I den offentlige arbejdsanvisning går skillelinierne primært mellem de faglærte forbund og Dansk

19. Aage Vater: »Arbejdsanvisningen i Danmark 1913-38«. København, 1938.

20. »Fagblad for Smede og Maskinarbejdere $\ll$, nr. 10/1913. 
Arbejdsmands Forbund. For Dansk Arbejdsmands Forbund betød 1913-loven en svækkelse af den funktionelle sammenhæng mellem arbejdsanvisning, arbejdsløshedskasse og fagforening.

\section{Statsliggørelsen socialdemokratisk set}

Socialpolitikken skal ifølge 2. Internationale/Kausky-traditionen bidrage til at udligne forskellene i eksistensvilkår i arbejderklassen, ligesom adgang til eksistensmidler udenom lønformen, i den socialdemokratiske arbejderbevægelse (Hilferding/SPD) er blevet opfattet som muligheden for at tilkæmpe sig en $»$ social « eller »politisk « $1 ø$ n.

Indenfor denne kontext blev arbejdsløshedslovene af den socialdemokratiske arbejderbevægelse opfattet som et moment i en langsigtet reformpolitisk strategi. Lovene blev fortolket som en anerkendelse af arbejderklassens legitime eksistensinteresser, og som en gennemgangslejr, eller en sejr, »som efterhånden skal føre til det store mål« (m.u.), der blev defineret som »arbejdernes ret til at være herrer over de $\varnothing$ konomiske love i samfundet $\aleph^{21}$.

På den ene side gik det socialdemokratiske projekt over det borgerligge parlament. Man var af den opfattelse, at kapitalismen i sin udvikling selv ville producere de sociale kræfter, som via stemmesedlen skulle virkeligg $\varnothing$ re statens overtagelse af produktionsmidlerne, indførelse af planøkonomi og dermed socialisme ${ }^{22}$. På den anden side var man ikke blind for markedsorganisationernes betydning for det socialdemokratiske projekt. I »Samarbejdet« hedder det således, at en styrkelse af

»arbejderorganisationerne netop (er, m.t.) vejen eller midlet. På den beror i virkeligheden alle sociale fremskridt. Jo stærkere organisationer, desto større fremskridt vil der opnås $\ll^{23}$.

I tilknytning hertil er det væsentligt at bemærke, at en styrkelse af den socialpolitiske indsats ikke blot og bart blev opfattet som et samfundsmæssigt udviklingsperspektiv. En række af 2. Internationales fremtrædende teoretikere, bl.a. Kautsky, betragtede socialpolitiske reformer som et praktisabelt alternativ til blot og bar ideologisk bevidstgørelse som fundament for opslutning og enhed i arbejderbevægelsen.

21. »Samarbejdet«, nr. 16/1904.

22. Som bl.a. påpeget af Karl-Heinz Roth i »Den »anden« Arbejderbevægelse«, GMT, 1976, har denne socialismeopfattelse sin rod i en arbejderbevægelse domineret af faglærte arbejdere. De faglærte arbejdere identificerer sig med »produktionsmålet«. »Derfor lå systemets grundlæggende modsigelse for dem heller ikke på fabriksplanet, deres socialistiske ideologi begyndte ved sfæren for merværdirealisering, ved konkurrencens skin, som det blot drejede sig om at få fjernet, for at gå over til socialismen, dvs. til en fremskyndet erhvervsøkonomisk udvikling. Overgangen til socialismen synes følgelig at være en relativt harmonisk og harmløs operation på samfundsplan«.

23. »Samarbejdet«, nr. 16/1904. 
Desangående må det errindres, at arbejdsløshedskasserne også efter 1907-lovens ikrafttræden, qua den tætte forbindelse mellem kasserne og fagforeningerne, forblev et fagforeningsmæssigt rekrutteringsinstrument. 1907-loven åbnede godt nok op for medlemsskab af kasserne uden et samtidigt medlemsskab i fagbevægelsen. Uden dette dobbelte medlemsskab blev kontingentet til kasserne imidlertid betragteligt forhøjet, og reelt blev indmeldelse i arbejdsløshedskasserne identisk med medlemsskab i fagbevægelsen. Med andre ord bidrog de statsliggjorte arbejdsløshedskasser til at øge den fagforeningsmæssige organisering, hvorved den socialdemokratiske arbejderbevægelse, ifølge egne forestillinger, magtmæssigt blev konsolideret.

For så vidt angår det sammenfaldende medlemsskab i arbejdsløshedskasser og fagforeninger, har 1907-loven langsigtet bidraget til, at der i Danmark i 1980'erne findes nogen af de højeste organisationsprocenter i Vesteuropa. I 1980 lå organisationsprocenten på 79 i Danmark, medens de tilsvarende tal lå på 54 i Storbritannien og 33 i Vesttyskland. ${ }^{24}$ Efter 1980 er forskellene mellem de tre lande vokset. Medens organisationsprocenten er steget i Danmark, er den faldet i såvel Storbritannien som Vesttyskland. Dette vil jeg begrunde med forskelle i arbejdsløshedskassernes statslige institutionaliseringsform i de tre lande. Disse forskelle skal nærmere behandles i det følgende afsnit.

\section{Statsliggørelsens ud- og afvikling}

På det generelle institutionelle plan lå 1907-loven i klar forlængelse af fagbevægelsens monopol-koncept og indre organisationsstrukturering. Såvel de offentlige arbejdsløshedskasser som arbejdsanvisningens funktionsmodus genspejlede den fagligt definerede struktur i fagbevægelsen. Med andre ord har arbejdsløshedslovene af 1907 og 1913 rødder i den danske arbejderbevægelses organisatoriske særtræk.

Koblingen mellem arbejderbevægelsen og statsfunktionernes institutionaliseringsform sættes i relief ved en sammenligning med f.eks. den italienske udvikling.

I Italien har fagbevægelsen sine rødder i de såkaldte »Camera del lavoro«. Disse var geografisk/bymæssigt afgrænsede organisationer, og i modsætning til den danske fagbevægelses vertikale organisationsstruktur organiserede de alle kategorier af arbejdere uanset uddannelsesbaggrund, fagtilknytning m.v. Dvs. at faglærte, ufaglærte, landarbejdere m.v. var indrammet $\mathrm{i}$ een og samme organisation. Organisationsformen blokerede for udviklingen af sektionalisme.

Også i Italien blev fagbevægelsen udgangspunkt for forsøg på at løse de arbejdsløses reproduktionsproblemer via oprettelsen af arbejdsløshedskasser.

24. Anders Kjellberg: »Facklig organisering i tolv länder«, Lund 1983. 
I 1910 var dog kun 50.000 arbejdere ud af 500.000 organiserede og en samlet arbejdsstyrke på 8 mill. omfattet af en arbejdsløshedsforsikring. ${ }^{25}$

I lighed med den danske arbejderbevægelse orienterede også den italienske sig mod staten med henblik på at løse arbejdsløshedsproblemerne. Modsat den danske fagbevægelse, stillede man krav om en helstatslig obligatorisk arbejdsløshedsforsikring. Dels var traditionen med frivillige kasser så svagt udviklet, at de ikke reelt udgjorde et grundlag der kunne bygges videre på. Dels korresponderede lønniveauet med (eller lå under) eksistensminimum. Selv en statslig subsidiering af frivillige arbejdsløshedskasser ville alene tilgodese de aller bedst stillede lag i arbejderklassen, og man frygtede, at denne type forsikring ville skabe lommer af priviligerede arbejderlag. Man mente at en obligatorisk forsikring var en grundbetingelse for at få inkluderet hele arbejderklassen i forsikringen; bl.a. de lavtlønnede sæsonarbejdende landarbejdere der udgjorde ca. $50 \%$ af arbejdsstyrken.

Jeg vil hævde at dette »klasse«-koncept korrelerer med fagbevægelsens organisationsmønster. Den horisontale fysionomi stimulerede en solidaritetsdannelse der rakte ud over snævre fagafgrænsede interesser. Den obligatoriske forsinkringsform afspejler med andre ord den brede klassesammensætning i »Camera del lavoro«.

Endvidere stillede man krav om at forsikringen alene skulle finansieres af arbejdsgivere og stat. Dette ville udmønte sig i en indirekte lønforhøjelse. I forsikringsformen lå en høj grænsenytte uden at der direkte blev grebet ind i løndannelsen. Modsat det danske system der byggede på høj grad af selvfinansiering og dermed var billigere for det offentlige og skatteyderne.

Med baggrund i en omfattende strejkebevægelse i 1918-19, en organisatorisk styrkelse af fagforeningerne og en politisk fremgang for arbejderbevægelsen ved parlamentsvalget i 1919, blev der pr. 1/1 1920 indført et obligatorisk forsikringssystem i Italien. I modsætning til kravet fra arbejderbevægelsens side blev forsikringen dog finansieret med 50\% fra hver af arbejdsmarkedets parter, ligesom landarbejderne i sammenhæng med en generel svækkelse af arbejderbevægelsen fra 1922 blev ekskluderet fra forsikringen i 1923.

Denne reference til Italien underst $\varnothing t t e r$ min antagelse om, at der med hensyn til formen for løsningen af arbejdsløshedsproblemerne eksisterer forbindelseslinier mellem fagbevægelsens indre organisationsstrukturering og arbejdsløshedsforsikringens statslige institutionaliseringsform.

Med Danmark og Italien som konkrete eksempler, kan man på et overordnet plan identificere to hovedtyper af forsikringssystemer. ${ }^{26}$ Det drejer

25. Gino Baglioni, Comune di Verona: »Il Comune moderno e la Disoccupazione operaia«, Tipografia Cooperativa, Verona, 1915.

26. For en diskussion af en tredje hovedvariant, nemlig den svenske »model«, hvor aktiv beskæftigelsespolitik har primat overfor arbejdsløshedsforsikringen, se Per H. Jensen: »Arbejdsløshedspolitikken 
sig dels om det helstatslige obligatoriske forsikringssystem. Dels om et forsikringssystem efter dansk mønster; eller den såkaldte »Ghent «-model. I Vesteuropa i dag findes »Ghent«-modellen kun i Danmark, Sverige og Finland.

Vedrørende afviklingen af statsfunktionerne gøres denne af Hansson/ Lærke Nielsen ${ }^{27}$ til en simpel refleks af akkumulationsudviklingen. De giver godt nok plads til lønarbejdernes interessekamp. Men ifølge forfatterne vil denne interessekamps retning og styrke i mere eller mindre formidlet form være afhængig af kapitalens ændrede arbejdskraftbehov.

Overfor Hansson/Lærke Nielsen skal jeg hævde den tese, at arbejdsløshedsforsikringens statslige institutionaliseringsform spiller en vigtig rolle for evnen til at forsvare og fastholde statsfunktionerne intakt. Denne tese skal nu afprøves ved at konfrontere »Ghent«-modellen og det helstatslige obligatoriske forsikringssystem under den aktuelle krise.

Et karakteristikum ved det obligatoriske system er, at forsikringen helt er institutionaliseret i staten. Den reguleres rent politisk, og de politiske styrkeforhold mellem »arbejderpartier« og borgerlige partier kan være helt afgørende for, hvordan den finansieres, administreres og for fastlæggelse af ydelsesniveau m.v. ${ }^{28}$ Hvad angår administrationen og reguleringen af ydelsesniveau og medlemsbidrag er helstatslige systemer således følsomme overfor styrkeforholdene i parlamentet, og hvem der har regeringsmagten. Lønmodtagerorganisationerne har ingen direkte indflydelse eller ret til at blive inddraget $\mathrm{i}$ forhandlingerne. Heroverfor er forvaltningen og administrationen af »Ghent «-modellen overdraget til fagbevægelsen, og tilsvarende er fagbevægelsen en naturlig forhandlingspartner ved eventuelle justeringer af forsikringen.

Videre regulerer de to forsikringssystemer på forskellig måde forholdet mellem beskæftigelse og arbejdsløse. Indenfor det helstatslige system er der ingen institutionelle forbindelser mellem fagbevægelsen og arbejdsløshedsforsikringen (de arbejdsløses forsørgelse), og der er ingen tilskyndelse for de arbejdsløse til at forblive i fagbevægelsen. I Vesttyskland og Storbritannien, hvor man har helstatslige forsikringssystemer, ekskluderes de arbejdsløse indenfor store erhvervsområder fra fagbevægelsen.

I Danmark, hvor forvaltningen af forsikringen er overdraget til fagbevægelsen, eksisterer i modsætning hertil en meget tæt forbindelse mellem fagbevægelse og arbejdsløshedsforsikringen. Identitetsforholdet mellem medlemsskab

i Sverige« $i$ Jørgensen/Toboe (red): »Fagbevægelse stat og kommuner«, Aalborg Universitetsforlag, 1985.

27. Finn Hansson/Peder Lærke Nielsen: »Statsintervention og reformismekritik«, $i$ Kurasje nr. $23 / 24 / 1980$.

28. Fritz von Nordheim Nielsen: »Det gensidige forhold mellem arbejderbevægelse og velfærdsstat «. PAVV-Arbejdspapir nr. 2/1985, Sociologisk Institut. 
af arbejdsløshedsforsikringen og fagbevægelsen gør, at de arbejdsløse forbliver i fagbevægelsen. Den institutionelle form lokaliserer så at sige beskæftigede og ubeskæftigede i samme organisation. Dermed bliver fagbevægelsen ikke kun en organisationsform for de beskæftigede, men for hele klassen, hvad der giver fagbevægelsen en større interesse i at kæmpe for de arbejdsløses eksistenssituation.

Samtidig er forsvarskampen funderet på et bredt grundlag. Selvom arbejdsløshedskasserne er fagligt afgrænset, har arbejdsløshedslovene bidraget til at skabe et nyt forhold mellem faglærte og ufaglærte. Interesserne er blevet homogeniseret. På tværs af faglige skel kan man stå samlet om at forsvare et understøttelsessystem, der delvis finansieres af staten. De arbejdsløse er ikke forskelsløst overladt til de parlamentariske styrkeforhold.

På det empiriske plan har denne særlige formidling mellem beskæftigede og ubeskæftigede såvel vist sin styrke under 30'er krisen som i 80'erne. I 30'erne gik det obligatoriske forsikringssystem rabundus i Storbritannien, ligesom problemerne omkring arbejdsløshedsforsikringens finansiering i Tyskland var et vigtigt moment for opløsningen af Weimar-koalitionen. Heroverfor oplevede man i Danmark kvalitetsmæssige bedringer af arbejdsløshedsunderst $\varnothing t t e l \operatorname{sen}^{29}$.

Det samme mønster har gjort sig gældende i 80'erne. I 1984 modtog

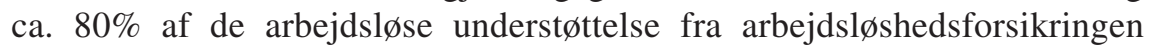
i Danmark ${ }^{30}$. I Vesttyskland modtog kun ca. 35\% af de arbejdsløse den forsikringsbaserede arbejdsløshedsunderstøttelse, hvad der bl.a. har sammenhæng med, at understøttelsen som i Storbritannien maximalt kan oppebæres 1 år. I Storbritannien og Vesttyskland er hovedparten af de arbejdsløse altså henvist til den meget lavere behovstestede socialhjælp. Ved en international sammenligning står det danske understøttelsessystem som problemløser med andre ord relativt uudfordret, uden at det dermed er sagt, at det ikke kunne være bedre.

Generelt kan man altså konkludere, at det danske understøttelsessystem har en høj kvalitet hvad angår evnen til problemløsning, samt at arbejdsløshedskassernes generelle organisatoriske/institionelle form har bidraget til meget høje organisationsprocenter i fagbevægelsen. Disse positive aspekter har mødt sin modstrøm i en stigende »fremmedstyring « af den »indre « organisationsverden. Der er sket en vækst i det byrokratiske system og reguleringsmekanismer. Omkostningerne har været en opstramning af de autonome principper i den »indre« organisationsverden.

29. Jan Peter Henriksen: »Forsørgelse og understøttelse i Danmark frem til 1945«, Sociologisk Institut, Københavns Universitet, 1985.

30. Arbejdsministeriet, Økonomisk-statistisk konsulent: »Arbejdsmarkedet og arbejdsmarkedspolitik«, september 1984, København. 


\section{Afslutning}

I sin berømte artikel: »The Welfare State in Historical Perspective ${ }^{31}$ hævder Asa Briggs, at arbejdsløshedsforsikringen spiller en strategisk rolle for såvel arbejderbevægelsens som velfærdsstatens udvikling, idet arbejdsløshed mere end noget andet tvang de tidligere fagforeninger til at skifte fra sektionalisme til at foretage generelle arbejderklasseovervejelser.

Jeg har med denne artikel forsøgt at vise, at den danske udvikling såvel rummer et sektionalistisk som klassemæssigt standpnkt. På den ene side medvirkede arbejdsløshedslovene i 1907 og 1913 til at reproducere den fagligt segregerede struktur i arbejderklassen. Arbejdsløshedskasserne var fagligt definerede, og forblev fagligt definerede efter 1907-reformen. På den anden side bidrog statsliggørelsen til at udligne eller modificere differentieringen i eksistensvilkår i arbejderklassen (2. Internationale konceptet). Før 1907 var det alene de bedst aflønnede grupper på arbejdsmarkedet, der besad det finansieringsmæssige grundlag for dannelsen af arbejdsløshedskasser. Indenfor områderne med stor arbejdsløshed og lav løn var de arbejdsløse henvist til den kommunale fattighjælp. Tilsyneladende er der altså en sammenhæng mellem problemlфsning for klassen som helhed og statslig integration ${ }^{32}$.

Ud fra sidstnævnte konstatering kan jeg dog ikke tilslutte mig Abrahamsons bemærkning om, at der for »revisionisterne eksisterer ... en tendens til at opfatte solidaritet og stat som en og samme sag «. Pointen er den omvendte. Det er den manglende evne til at slå bro over de klasseinterne modsætninger, der udløser den statslige reformpolitiske orientering.

Der er skrevet lange afhandlinger om, at statslig socialpolitik blot og bart handler om en klasseintern omfordeling. Ud fra Abrahamsons standpunkt må man derfor spørge, hvorfor en sådan omfordeling aldrig er kommet i stand på frivillig basis? I Abrahamsons forståelsesunivers ville dette være »ægte« solidaritet. I fagbevægelsen kunne man jo »bare « have oprettet en fælles kasse for alle, herunder de ufaglærte lønarbejdere, som alternativ til den statslige reformudvikling.

Den danske arbejderbevægelse står ikke erfaringsløs overfor tiltag i denne retning. På initiativ af Pio's Internationalen forsøgte man i 1870'erne at opløse de fagforeningstilknyttede fagligt afgrænsede sygekasser i een stor kasse

31. Asa Briggs: »The Welfare State in Historical Perspective « $i$ Archives Européennes de Sociologie, Tome II, 1961, No. 2.

32. Pointen i denne paragraf skal modificeres derhen, at de ikke fagligt organiserede forud for statsliggørelsen var helt udelukket fra forsikringen. Identitetsforholdet mellem medlemsskab af fagforening og arbejdsløshedskasse videreførte i grove træk dette forhold efter statsliggørelsen. Versus det obligatoriske forsikringssystem handlede statsliggørelse altså primært om problemløsning for de organiserede dele af klassen. I dette aspekt fungerede forsikringen som rekrutterende til fagbevægelsen. 
dækkende hele klassen. Modstand for de faglige sektioners side resulterede $\operatorname{dog} \mathrm{i}$, at forsøget $l \emptyset \mathrm{b}$ ud i sandet.

De modsatrettede eksistensinteresser, som man ikke blot voluntaristisk kan sætte sig ud over ved at hævde princippet om selvorganiserede løsninger på klassens eksistenssituation, er givet ved den samfundsmæssige og virksomhedsinterne arbejdsdeling. Arbejdsdelingen reproduceres organisatorisk i fagbevægelsens sektionalisering og sætter grænser for solidaritetsformernes udvikling. Tilsvarende genspejlede opbygningen af de autonome arbejdsløshedskasser differentieringerne i eksistensvilkår og den fagligt definerede struktur i fagbevægelsen.

At arbejdsløshedskasserne blev fagligt defineret har sine rødder i forholdet mellem fagforeningerne og arbejdsløshedskasserne. I en vis forstand kan man tale om, at fagforeningerne og arbejdsløshedskasserne udgør komplementære organisationsformer med en gensidig ind- og tilbagevirkning i form af rekruttering til fagbevægelsen, en styrkelse af lønkampens betingelser ved at afskærme reservearmeens tryk m.v. Historisk er det da også fagbevægelsen, der har virket som dynamo ved en organisering af klassen omkring arbejdsløshedsproblemerne. Tilsvarende har arbejdsløshedskassernes organisationskoncept sit udspring i fagforeningerne som markedsorganisationer og tenderer til at følge strukturen i fagbevægelsens opbygning.

Analogt hermed udspringer arbejderbevægelsens målforestillinger og handlingslogik i forhold til en statslig løsning af arbejdsløshedsproblemerne af bevægelsens organisatoriske og politiske tradition. For så vidt angår den danske erfaring afspejler statsliggørelsens instionaliseringsform således følgende faktorer: At fagbevægelsen var fagligt afgrænset og domineret af faglærte arbejdere. At der eksisterer en lang forudgående tradition med frivillige kasser, og at store dele af de bedst stillede lag af arbejderklassen tilhørte en fagforeningstilknyttet arbejdsløshedsforsikring.

Arbejdsløshedsforsikringens institutionaliseringsform får langtrækkende konsekvenser. Der er en kobling mellem institutionaliseringsform og (grad af) afvikling af statsfunktionerne i 1980 'erne. Som vist betinger institutionaliseringens form mulighederne for at lade modsætningsforholdet mellem lønarbejde og kapital komme til udtryk. Da imidlertid institutionaliseringsformen prages af arbejderbevægelsens karakter og struktur på tidspunktet for statsliggørelsen, i Danmark altså i 1907, må man konstatere, at det er »pure luck «, at det danske understøttelsessystem i 1980'erne har overlevet noget mere intakt end tilfældet har været i f.eks. Vesttyskland og Storbritannien. Firkantet sagt har den danske erfaring i sin langsigtede udvikling været prædisponeret af 1907-reformen.

Ud fra de mange facetter i arbejdsløshedslovgivningen fokuserer Holm, Frandsen og Møller primært på udviklingen i den »indre« organisationsverden med henblik på at drive deres »kritiske« pointer i land. Jeg skal medgive, at 
der for så vidt angår den »indre« organisationsverden er sket en vækst i det byrokratiske system og reguleringsformer. Jeg vil dog hævde, at de nævnte foranstaltninger allerede lå prædisponeret $\mathrm{i}$ arbejderklassens egne »normer for solidaritet «:

- arbejdsløshedskassernes midler var allerede forud for statsliggørelsen adskilt fra fagforeningernes $\emptyset$ konomi og strejkekasserne; herunder er det blevet understreget, at en række strejkekasser $\emptyset$ konomisk blev styrket via statsliggørelsen af arbejdsløshedskasserne.

- allerede i de autonome arbejdsløshedskasser lå en disciplinering til lønarbejdet, eller det Holm foragteligt kalder kravet om »klientværdig adfærd «; adgang til arbejdsløshedsunderstøttelse forudsatte 1-2 års regelmæssige præmieindbetalinger/beskæftigelse, ligesom kontrollen fra »neden« af de arbejdsløse var restriktiv.

I store træk fungerede regelsættene i de autonome arbejdsløshedskasser som forformer for de senere statslige kontrolforanstaltninger.

Samtidig vil jeg med Blanke ${ }^{33}$ gøre opmærksom på, at statsliggørelsen har skabt ændringer i problemstillingen. Med statsliggørelsen opstår en række nye dilemmaer og nye perspektiver i kampen, der handler om at »varne om de tilkæmpede positioner « (m.u.). Der har altså historisk i arbejderbevægelsen løbende været truffet et valg indenfor spændingsfeltet: øget »indre« kontrol og statssubsidier.

I denne forbindelse har det yderligere unddraget sig Holm, Frandsen og Møllers opmærksomhed, at der ikke lå nogen tvang til statsliggørelse af de autonome arbejdsløshedskasser. Det var frivilligt for kasserne, om man ville søge om statsanerkendelse, og beslutningen blev truffet af medlemmerne i de autonome arbejdsløshedskasser. Straks efter 1907-reformen søgte samtlige autonome arbejdsløshedskasser om statsanerkendelse. Polemisk kan man med Mogens Holms formuleringer derfor sige, at »evnen til erfaringsindsamling i kollektive sammenhænge« og det »at gøre erfaringer, og gøre erfaring med erfaringerne « entydigt pegede på en statsliggørelse af de autonome arbejdsløshedskasser. Dette forhold er ikke blevet uaktuelt. Muligheden for at frasige sig statsanerkendelsen/de statslige subsidier og derigennem genvinde det »tabte« »selvrådige demokrati« eksisterer fortsat i 1980'erne.

I kravet om en ny-organisering omkring svigt i lønformsreproduktionen som alternativ til velfærdsstaten opstiller Mogens Holm følgende udviklingsperspektiv: »demokratisering af institutionerne, fjernelse af den sociale kontrol og overførsel af midler for det sociale område til arbejderklassens selvforvaltning «. Formuleringen lyder umiddelbart flot. Samtidig er den dog svær at gennemskue for så vidt angår dens aktuelle og praktiske relevans for politiske og strategiske overvejelser.

33. Bernhard Blanke, 1981, op.cit. 
Jeg har således i denne artikel søgt at udrede to forhold: For det første at arbejdsløshedskasserne er en form for overførsel af midler til arbejderklassens selvforvaltning. For det andet at arbejderklassens evne til selvorganisering følger de klasseinterne differentieringer. Der er en tendens til, at alene de »aristokratiske « dele af klassen formår at organisere sig omkring »mangelsituationer « $\mathrm{i}$ forhold til lønformsreproduktionen. Uden at koble diskussionen af selvorganisering til problemløsning for klassen som helhed bliver diskussionen i bedste fald ligegyldig. Derfor må debatten om en styrkelse af selvorganisering og de sociale netværk nødvendigvis føres meget konkret og forbindes med de historisk udviklede materialitets-/kampformer og de muligheder for solidaritetsdannelse som er knyttet hertil. Samt: hvordan skal forbindelseslinierne mellem den selvorganiserede socialpolitik og lønkampen (fagforeningerne) etableres?

Det kunne bidrage til diskussionen at gøre de historiske erfaringer med selvorganisering og de sociale netværk til genstand for en dybere analytisk opmærksomhed. Det er rigtigt, at der qua velfærdsstatens fremmarch mellem stat og brugere af de socialpolitiske ydelser er skabt et »klientforhold«, og at de mellemmenneskelige relationer i de moderne storbysamfund underlægges valoriseringsimperativerne. Der er tale om en forarmelse af hverdagslivet. Til gengæld åbner anonymiseringen i storbysamfundet og i forhold til forsørgelsesapparaterne muligheder for at leve sit eget liv. Og er dette trods alt ikke at foretrække frem for et system, hvor naboer og »kammerater er med til at betale «, og hvor gensidig mistænkeliggørelse og sanktioner overfor afvigende adfærd let kommer til at indgå som et centralt moment i det sociale liv? Forsvinder f.eks. hetzen mod bistandsklienterne fordi forvaltningen af deres forsørgelse bringes ud i demokratiske nær-miljøer, eller vil forfølgelsen af de udgrænsede befolkningsgrupper blot antage nye og måske mere afskyelige former? Sporene skræmmer. Det var i et lille dansk nærmiljø at Sandemose erfarede og nedfældede $»$ Janteloven $«$. 